Check for updates

Cite this: Chem. Sci., 2019, 10, 879

๑ All publication charges for this article have been paid for by the Royal Society of Chemistry

Received 3rd September 2018

Accepted 1st November 2018

DOI: $10.1039 / \mathrm{c} 8 \mathrm{sc} 03917 \mathrm{~h}$

rsc.li/chemical-science

\section{Two-photon fluorescence imaging reveals a Golgi apparatus superoxide anion-mediated hepatic ischaemia-reperfusion signalling pathway $\dagger$}

\author{
Wen Zhang, $\$$ Jiao Zhang, $\$$ Ping Li, ${ }^{*}$ Jihong Liu, Di Su and Bo Tang (D) *
}

Hepatic ischaemia-reperfusion (IR) injury is mainly attributed to a burst of reactive oxygen species (ROS) that attack biological macromolecules and lead to cell death. The superoxide anion $\left(\mathrm{O}_{2}{ }^{-}\right)$is the first ROS to be generated and triggers the production of other ROS; thus, explorations of the role of $\mathrm{O}_{2}{ }^{\cdot-}$ in the IR process are meaningful. Meanwhile, the Golgi apparatus generates $\mathrm{O}_{2}{ }^{\cdot-}$ via Golgi-associated proteins, which might play an essential role in IR injury. However, the molecular mechanism by which $\mathrm{O}_{2}{ }^{-}$from the Golgi apparatus regulates hepatic IR injury is unclear. Therefore, to solve this problem, a two-photon (TP) excited fluorescence probe (CCA) was designed and prepared for the reversible detection of $\mathrm{O}_{2}{ }^{-}$in the Golgi apparatus. With the assistance of TP fluorescence microscopy, we observed a substantial increase in the levels of $\mathrm{O}_{2}{ }^{--}$in the Golgi apparatus of an IR mouse liver for the first time, as well as increased caspase- 2 activity and apoptosis. Furthermore, we found that the tumour necrosis factor (TNF- $\alpha$ ) functions as a positive mediator of $\mathrm{O}_{2}{ }^{\cdot-}$ generation. Based on these data, we identified the potential signalling pathway in the Golgi that mediates $\mathrm{O}_{2}{ }^{--}$fluctuations in IR mice and revealed the related molecular mechanisms; we also provide a new target for treating IR injury.

\section{Introduction}

An interruption in hepatic blood flow is an inherent phenomenon during diverse types of hepatic surgery. ${ }^{1}$ Once the blood flow and oxygen supply are restored, the liver is subjected to a further insult, aggravating the injury. ${ }^{2}$ Hepatic ischaemia reperfusion (IR) injury is attributed to the damage caused by reactive oxygen species (ROS), ${ }^{3}$ such as the superoxide anion $\left(\mathrm{O}_{2}{ }^{--}\right),{ }^{4,5}$ hydrogen peroxide $\left(\mathrm{H}_{2} \mathrm{O}_{2}\right),{ }^{6}$ and peroxynitrite $\left(\mathrm{ONOO}^{-}\right){ }^{7}$ Because the superoxide anion $\left(\mathrm{O}_{2}{ }^{-}\right)$is the first ROS to be generated and can trigger and regulate the production of other ROS, ${ }^{8}$ explorations of the role of $\mathrm{O}_{2}{ }^{--}$in the IR process are meaningful.

The Golgi apparatus is an important organelle responsible for protein processing, classification and packaging, thus maintaining the normal function and survival of cells. ${ }^{9}$ Meanwhile, the Golgi apparatus generates $\mathrm{O}_{2}{ }^{-}-$via Golgi-associated proteins such as $\mathrm{NOS}^{\mathbf{1 0}}$ and releases $\mathrm{O}_{2}{ }^{--}$when it catalyses reactions with substrate molecules. Under normal circumstances, the low levels of $\mathrm{O}_{2}{ }^{-}$in the Golgi body is catalytically transformed to $\mathrm{H}_{2} \mathrm{O}_{2}$ by SOD, which acts as a second messenger. However, when the body

College of Chemistry, Chemical Engineering and Materials Science, Collaborative Innovation Center of Functionalized Probes for Chemical Imaging in Universities of Shandong, Key Laboratory of Molecular and Nano Probes, Ministry of Education, Institutes of Biomedical Sciences, Shandong Normal University, Jinan 250014, People's Republic of China.E-mail: lip@sdnu.edu.cn; tangb@sdnu.edu.cn

$\dagger$ Electronic supplementary information (ESI) available. See DOI: 10.1039/c8sc03917h

\$ These authors contributed equally to this work. is subjected to IR, the $\mathrm{O}_{2}{ }^{--}$levels fluctuate abnormally, leading to an imbalanced redox state in the Golgi body. More likely, these unbalanced Golgi $\mathrm{O}_{2}{ }^{-}$levels directly participate in IR injury. However, the number of studies focusing on the relationship between $\mathrm{O}_{2}{ }^{-}-$levels in the Golgi apparatus and IR injury is limited, although some studies have referred to mitochondrial $\mathrm{O}_{2}{ }^{--}$fluctuations during IR. ${ }^{11}$ Therefore, an accurate analysis of the changes in Golgi $\mathrm{O}_{2}{ }^{--}$levels and their effects on the process of IR injury will provide a more comprehensive understanding of pathogenesis, which can assist with the identification of a target for the treatment of this disease. However, the main obstacle is the lack of ideal analytical tools.

Fluorescence microscopy techniques offer many benefits ${ }^{12-24}$ and are ideal methods for detecting Golgi $\mathrm{O}_{2}{ }^{--}$levels. ${ }^{25-29}$ Fluorescent probes designed to detect $\mathrm{O}_{2}{ }^{-}-$levels in the Golgi apparatus are rare. Therefore, we designed and synthesized a new $\mathrm{O}_{2}{ }^{--}$ two-photon fluorescence probe that targets the Golgi and dynamically and reversibly detects $\mathrm{O}_{2}{ }^{--}$levels (cis-caffeic acid, CCA, Scheme 1). The CCA probe was designed using the following strategy: 1, a caffeic acid group for detecting the dynamic responses of $\mathrm{O}_{2}{ }^{--}$that displays blue fluorescence; and 2, an L-cysteine group for targeting the Golgi apparatus. ${ }^{30}$ Because Golgi apparatus contains many receptors for the cysteine residues or cysteine rich region. ${ }^{32,33}$ So L-cysteine is more easily to anchor in Golgi apparatus. Furthermore, the Huang group ${ }^{31}$ has been proved that probe with L-cysteine could targeting Golgi apparatus. With the aid of two-photon fluorescence microscopy, we detected Golgi $\mathrm{O}_{2}{ }^{-}$- fluctuations in IR mice. We also used this approach to study 

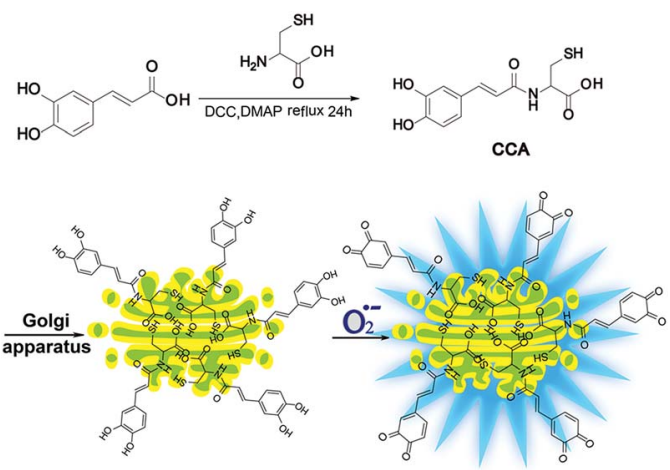

Scheme 1 The synthesis and luminescence mechanism of CCA.

related signalling pathways and illuminate the molecular mechanism by which $\mathrm{O}_{2}{ }^{\cdot-}$ regulates IR.

\section{Results and discussion}

\section{The synthesis and properties of CCA}

CCA was constructed with an amido linkage between the caffeic acid group and $\mathrm{L}_{\mathrm{L}}$-cysteine (ESI $\left.\dot{\dagger}\right)$. According to the probe design strategy, the blue fluorescence $(495 \mathrm{~nm})$ was dramatically increased with the addition of $\mathrm{O}_{2}{ }^{-}$(Fig. 1A, fluorescence quantum yield $=0.21$ ). Two-photon excited fluorescence responses to $\mathrm{O}_{2}{ }^{\cdot-}$ were identical (Fig. S1, $\uparrow$ two-photon absorption cross section $=38.7 \mathrm{GM})$. Fig. $1 \mathrm{~A}$ and $\mathrm{B}$ also illustrate the linear relationship between the fluorescence intensity ratio and
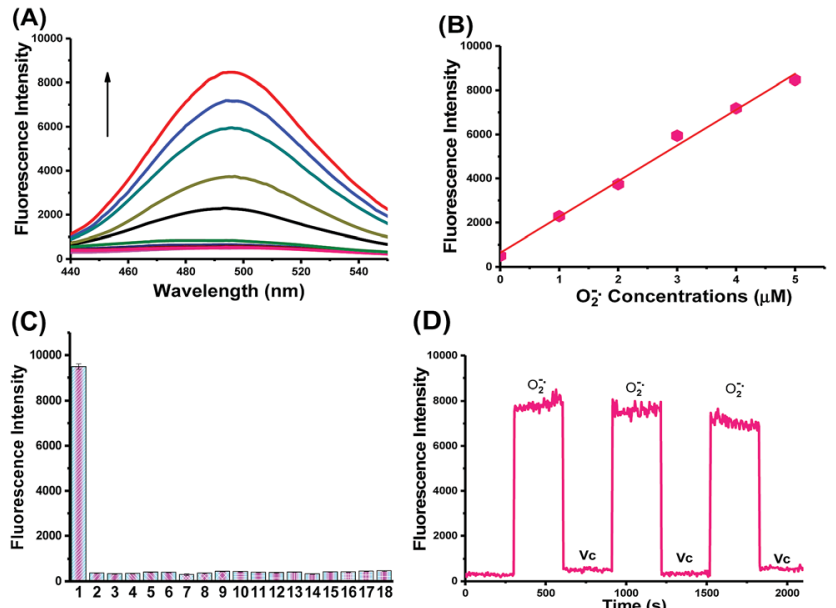

(D)

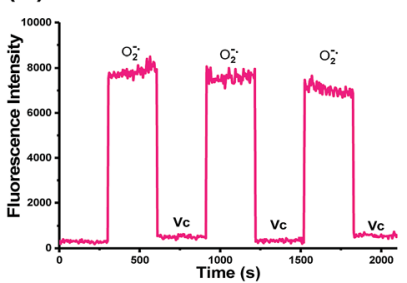

Fig. 1 Fluorescence properties of the CCA probe for $\mathrm{O}_{2}{ }^{--}$detection. (A) One-photon fluorescence spectra of $10 \mu \mathrm{M} \mathrm{CCA}$ after the addition of various concentrations of $\mathrm{O}_{2}{ }^{--}(0-5 \mu \mathrm{M})$. (B) A linear correlation between the ratio of the fluorescence intensity and $\mathrm{O}_{2}{ }^{--}$concentrations. (C) Fluorescence responses of $10 \mu \mathrm{M}$ CCA to various reactive oxygen species, reactive nitrogen species and metals $\left(5 \mu \mathrm{M} \mathrm{O}_{2}{ }^{-}\right.$, $20 \mu \mathrm{M}$ GSH, $100 \mu \mathrm{M}$ TBHP, $10 \mathrm{mM} \mathrm{H}_{2} \mathrm{O}_{2}, 1 \mu \mathrm{M}^{1} \mathrm{O}_{2}, 1 \mu \mathrm{M} \cdot \mathrm{OH}, 2 \mu \mathrm{M}$ $\mathrm{ONOO}^{-}, 50 \mu \mathrm{M} \mathrm{NO}, 100 \mu \mathrm{M} \mathrm{NaClO}, 10 \mathrm{mM} \mathrm{Na}^{+}, 10 \mathrm{mM} \mathrm{K}^{+}, 500 \mu \mathrm{M}$ $\mathrm{Ca}^{2+}, 500 \mu \mathrm{M} \mathrm{Zn}^{2+}, 500 \mu \mathrm{M} \mathrm{Fe}^{2+}, 500 \mu \mathrm{M} \mathrm{Fe}^{3+}, 20 \mu \mathrm{M} \mathrm{Cu}^{2+}$ and $20 \mu \mathrm{M}$ $\mathrm{Cu}^{+}$). (D) Reversibility of CCA fluorescence in the presence of alternating treatments with $5 \mu \mathrm{M} \mathrm{O}_{2}{ }^{-}$and $0.5 \mathrm{mM}$ ascorbic acid (Vc). All one-photon spectra were acquired in cell extracts at $\lambda_{\mathrm{ex}}=370 \mathrm{~nm}$ and $\lambda_{\mathrm{em}}=490 \mathrm{~nm}$.
$\left[\mathrm{O}_{2}{ }^{--}\right]$in a wide range of $0-5 \mu \mathrm{M}$. The linear equation was $F=$ $1621.514\left[\mathrm{O}_{2}{ }^{-}\right](\mu \mathrm{M})+631.98$, with a linear correlation coefficient of 0.991 and a detection limit of $18 \mathrm{nM}$. Collectively, CCA potentially possessed the ability to detect $\mathrm{O}_{2}{ }^{-}$, as determined by the blue fluorescence intensity.

Next, we examined the selectivity of CCA for $\mathrm{O}_{2}{ }^{--}$under simulated physiological conditions. ${ }^{33,34}$ The fluorescence responses of CCA to competing ROS, reactive nitrogen species (RNS) and metal ions are shown in Fig. 1C, S2 and S3. $\dagger$ As expected, CCA exhibited high selectivity for $\mathrm{O}_{2}{ }^{--}$. The $\mathrm{pH}$ titration experiment revealed that the CCA fluorescence intensity was basically maintained at a constant value at $\mathrm{pH}$ 4.0-9.0. Based on these findings, CCA exclusively captures $\mathrm{O}_{2}{ }^{--}$levels in living cells. Additionally, CCA possesses more advantages, including a fast fluorescence response to $\mathrm{O}_{2}{ }^{\cdot-}$, reversible detection of $\mathrm{O}_{2}{ }^{--}$and ascorbic acid ( $\mathrm{Vc}$ ) and no marked cytotoxicity at concentrations less than $5.13 \mathrm{mM}$ (Fig. 1D, S4 and S5†). Thus, CCA can serve as a robust sensor to achieve dynamic fluorescence imaging of $\mathrm{O}_{2}{ }^{\cdot-}$.

\section{Validation of CCA for the imaging of living cells}

The utility of CCA for fluorescence imaging in living cells was evaluated. We used 2-methoxyestradiol ${ }^{35,36}\left(2-\mathrm{ME}, 1.0 \mu \mathrm{g} \mathrm{mL}^{-1}\right)$ to inhibit both copper-zinc and manganese superoxide dismutases and determine the resulting increase in $\mathrm{O}_{2}{ }^{-}$concentrations, and Vc was to induce the reduction reaction of the CCA product in hepatocytes. As illustrated in Fig. 2, strong blue fluorescence was observed in hepatocytes treated with 2-ME compared with the control cells, indicating significantly increased $\mathrm{O}_{2}{ }^{--}$concentrations. After the addition of $1.0 \mathrm{mM}$ Vc to these cells, the fluorescence ratio decreased immediately, indicating redox reversibility. Furthermore, other reversible fluorescence changes were observed following successive treatments with 2-ME and Vc. We specifically reduced $\mathrm{O}_{2}{ }^{--}$levels using the $\mathrm{O}_{2}{ }^{--}$scavenger Tiron $(10 \mu \mathrm{M})$ to further confirm the selectivity of CCA for $\mathrm{O}_{2}{ }^{--}$in living cells. ${ }^{37}$ Fig. 2 shows weak fluorescence in hepatocytes treated with Tiron. Thus, the blue fluorescence of CCA changes according to the $\mathrm{O}_{2}{ }^{--}$fluctuations. Based on these results, CCA selectively and reversibly responds to $\mathrm{O}_{2}{ }^{--}$at the cellular level.

\section{Validation of CCA for the imaging of mice}

Next, we performed in vivo imaging of $\mathrm{O}_{2}{ }^{-{ }^{-}}$levels in mice based on the favourable two-photon excited fluorescence properties of CCA. Consistent with the design used for cellular imaging, we used 2-ME and Tiron to increase or decrease the $\mathrm{O}_{2}{ }^{--}$concentrations. As shown in Fig. 2B, more intense blue fluorescence was observed in mice treated with 2-ME and weak fluorescence was observed in mice treated with Tiron compared with the normal group, indicating an increase or decrease in $\mathrm{O}_{2}{ }^{--}$ concentrations, respectively. Thus, CCA visualized $\mathrm{O}_{2}{ }^{--}$fluctuations in small animals and achieved imaging at relatively deep levels in the tissue (depth $=350 \mu \mathrm{m})$.

\section{Golgi apparatus localization of CCA}

We performed an imaging experiment to determine whether CCA specifically targeted the Golgi apparatus. 2-ME stimulated hepatocytes were co-cultured with CCA and various commercial 

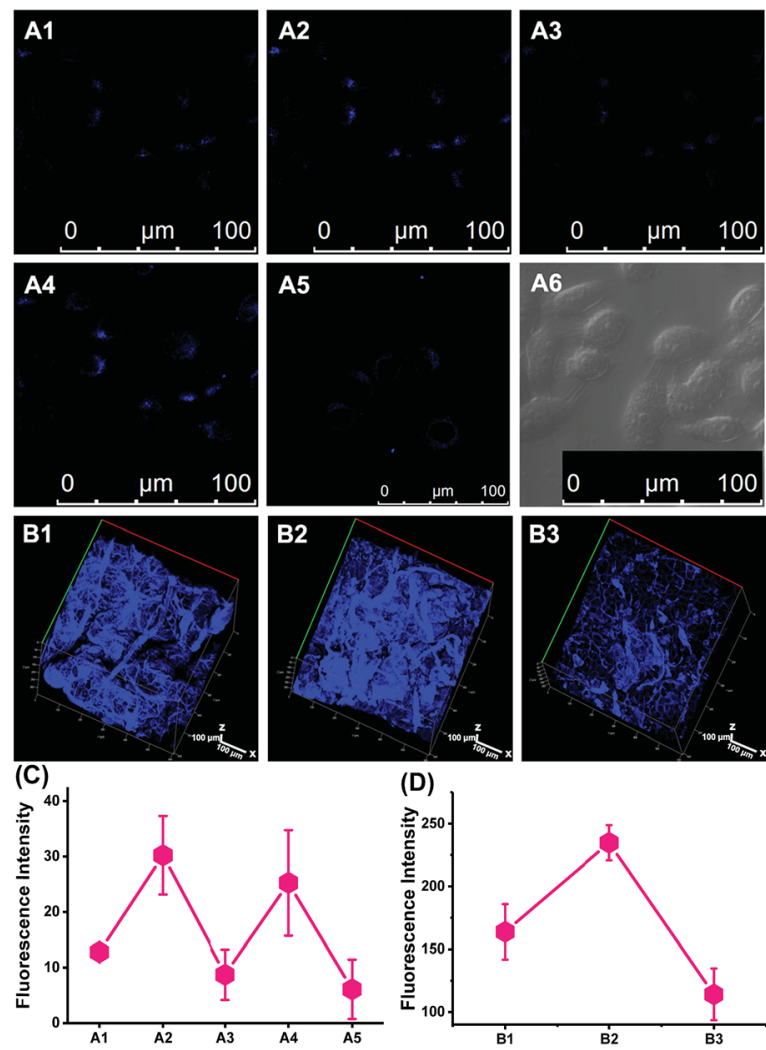

(D)
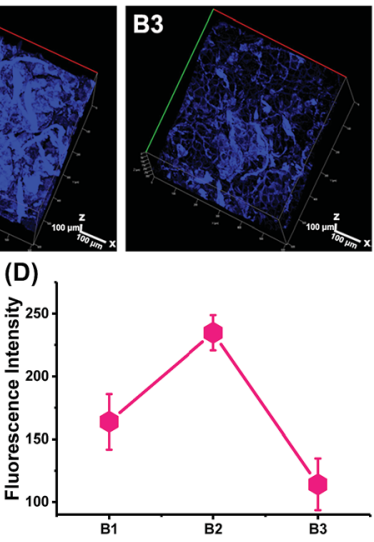

Fig. 2 TP fluorescence imaging of $\mathrm{O}_{2}{ }^{-}-$levels in hepatocytes and in mice. (A) Hepatic cells shown in (A1) were incubated with $10 \mu \mathrm{M}$ CCA for $10 \mathrm{~min}$. (A2) Cells shown in (A1) were stimulated with $1.0 \mu \mathrm{g} \mathrm{mL}^{-1}$ 2-methoxyestradiol (2-ME). (A3) Cells shown in (A2) were treated with $1.0 \mathrm{mM}$ Vc. (A4) Cells shown in (A3) were stimulated with $1.0 \mu \mathrm{g} \mathrm{mL}^{-1}$ 2-ME again. (A5) Cells were loaded with $10 \mu \mathrm{M}$ Tiron 30 min before the addition of CCA. (A6) Bright field images. (B) In vivo 3D images of normal animals (B1), 2-ME stimulated mice (B2) and Tiron-treated mice following an injection of $10 \mu \mathrm{M} C C A$. (C) The average fluorescence intensity output of (A). (D) The average fluorescence intensity output of (B). Images were acquired at an excitation wavelength of $800 \mathrm{~nm}$ and emission wavelengths corresponding to the blue channel of $430-530 \mathrm{~nm}$.

organelle dyes, including Golgi-Track Red, ${ }^{38}$ Mito-Tracker Deep Red, Lyso-Tracker Deep Red and ER-Tracker Red. The overlapped fluorescence images in Fig. 3A indicated that CCA fluorescence merged well with that of Golgi-Track Red and Pearson's colocalization coefficient was $0.93 .^{39}$ In contrast, CCA displayed almost no fluorescence inside the mitochondria (Fig. 3B, colocalization coefficient 0.15), lysosomes (Fig. 3C, colocalization coefficient 0.25 ) and endoplasmic reticulum (Fig. 3D, colocalization coefficient 0.24 ). These data provide strong evidence that the probe predominantly accumulates in the Golgi apparatus and reflects the Golgi $\mathrm{O}_{2}{ }^{--}$level.

\section{Increased $\mathrm{O}_{2}^{\cdot-}$ levels in the Golgi apparatus of IR cells and mice}

We established IR cell and mouse models by simulating liver surgery. ${ }^{\mathbf{4 0 , 4 1}}$ With the assistance of two-photon fluorescence microscopy, we imaged $\mathrm{O}_{2}{ }^{--}$fluctuations in the Golgi apparatus of IR cells and mice. As shown in Fig. 4, IR groups exhibited
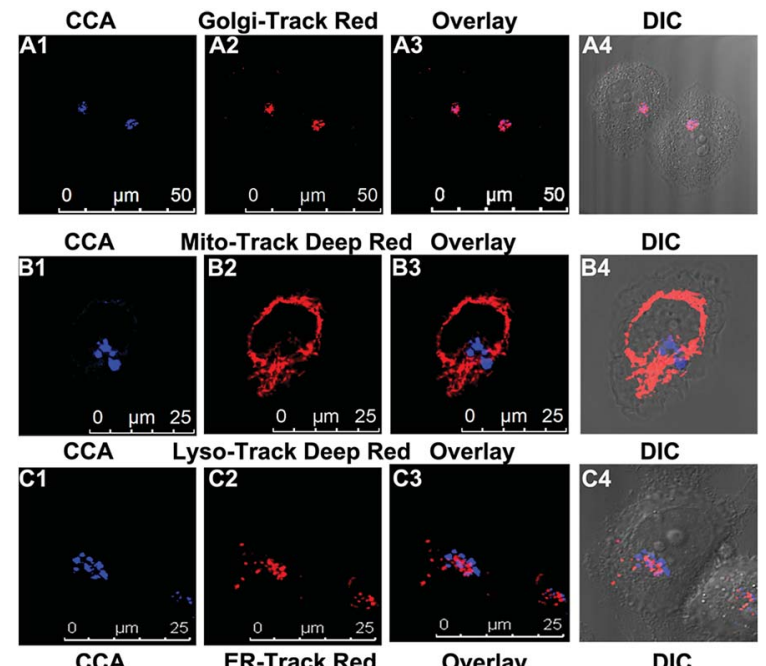

Mito-Track Deep Red Overlay

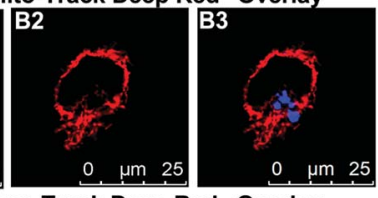

DIC
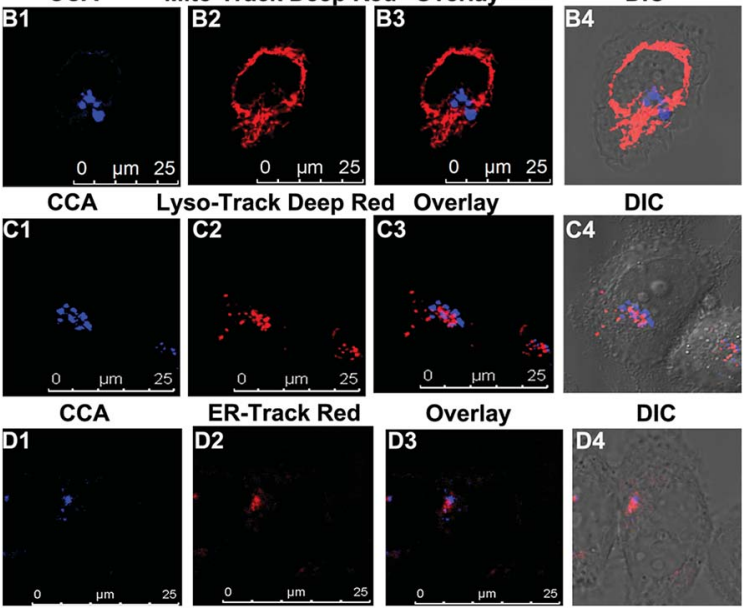

DIC

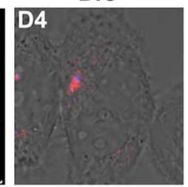

Fig. 3 Images of the intracellular localization and Golgi apparatustargeting capability of CCA. Hepatic cells were co-cultured with 2-ME $\left(1.0 \mu \mathrm{g} \mathrm{mL}^{-1}\right), \mathrm{CCA}\left(10 \mu \mathrm{M}, \lambda_{\mathrm{ex}}=405\right.$ and $\left.\lambda_{\mathrm{em}}=430-550 \mathrm{~nm}\right)$ and organelle dyes, including Golgi-Track Red $\left(50 \mathrm{nM}, \lambda_{\mathrm{ex}}=561 \mathrm{~nm}\right.$ and $\left.\lambda_{\mathrm{em}}=600-750 \mathrm{~nm}\right)$, Mito-Tracker Deep Red $\left(100 \mathrm{nM}, \lambda_{\mathrm{ex}}=633 \mathrm{~nm}\right.$ and $\left.\lambda_{\mathrm{em}}=650-740 \mathrm{~nm}\right)$, Lyso-Tracker Deep Red $\left(100 \mathrm{nM}, \lambda_{\mathrm{ex}}=\right.$ $633 \mathrm{~nm}$ and $\left.\lambda_{\mathrm{em}}=650-740 \mathrm{~nm}\right)$ and ER-Tracker Red $\left(500 \mathrm{nM}, \lambda_{\mathrm{ex}}=\right.$ $561 \mathrm{~nm}$ and $\lambda_{\mathrm{em}}=580-630 \mathrm{~nm}$ ).

strong blue fluorescence compared with normal groups of both living cells and mice in vivo, indicating that IR increased $\mathrm{O}_{2}{ }^{--}$ levels in the Golgi apparatus. We are the first to discover the connection between the IR process and Golgi $\mathrm{O}_{2}{ }^{-}-$levels in living cells and in vivo.
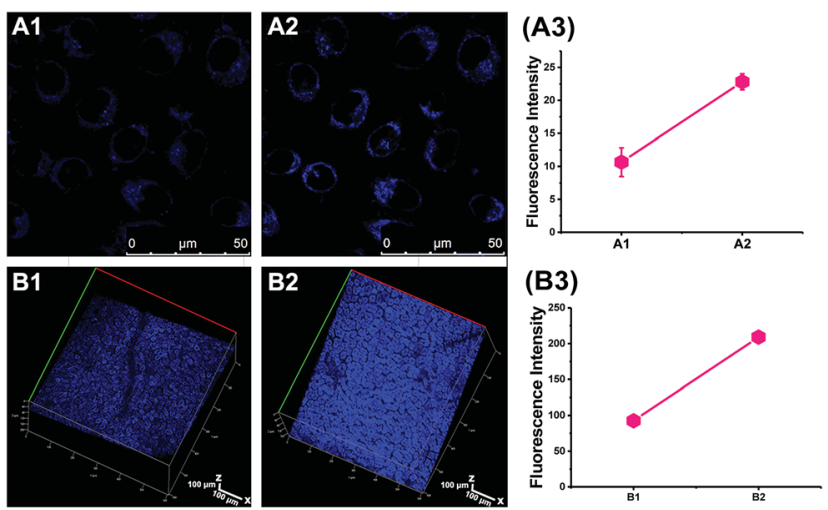

Fig. 4 Increased $\mathrm{O}_{2}{ }^{--}$levels in IR cells and mice. (A) The normal (A1) and IR hepatic (A2) cells were loaded with $10 \mu \mathrm{M}$ CCA for blue fluorescence imaging, and (A3) shows the average fluorescence intensity output of (A). (B) The in vivo 3D images of normal (B1) and IR mice (B2) injected with $10 \mu \mathrm{M} \mathrm{CCA}$ for blue fluorescence imaging are shown, and (B3) shows the average fluorescence intensity output of (B). Images were acquired at an excitation wavelength of $800 \mathrm{~nm}$ and emission wavelengths corresponding to the blue channel of $430-530 \mathrm{~nm}$. 
(A1)
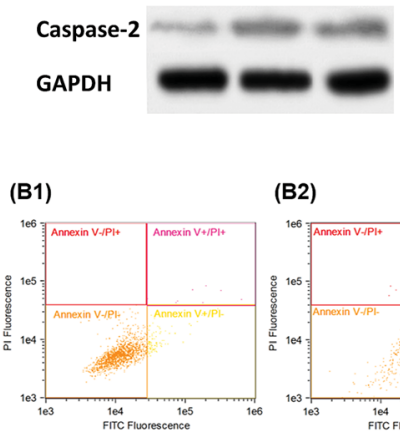

(B2)

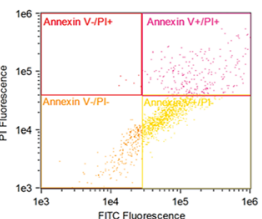

(B3)

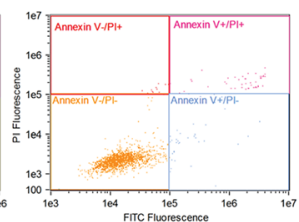

Fig. 5 Increased Golgi $\mathrm{O}_{2}{ }^{\cdot-}$ levels, caspase-2 levels and apoptosis in IR cells. (A1) Western blot showing caspase-2 levels in normal cells, IR hepatic cells and $10 \mu \mathrm{M}$ Tiron-treated cells. (A2) The average intensity output of the cells shown in (A1). (B) Flow cytometry analysis of normal cells (B1), IR hepatic cells (B2) and IR cells with $10 \mu \mathrm{M}$ Tiron (B3).

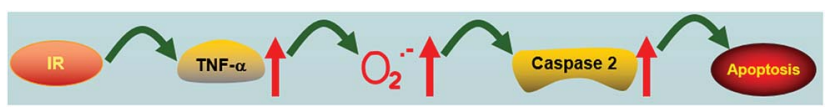

Fig. 6 Model for the signalling role of $\mathrm{O}_{2}{ }^{--}$in IR cells and mice.

\section{Increased $\mathrm{O}_{2}{ }^{\cdot-}$ levels in the Golgi apparatus induced apoptosis}

We next investigated the influence of excess $\mathrm{O}_{2}{ }^{\cdot-}$ levels in the Golgi apparatus on the levels of the pro-apoptotic protein caspase-2 and cell survival in IR hepatocytes. In Fig. 5A, high levels of $\mathrm{O}_{2}{ }^{--}$in the Golgi increased the caspase-2 level and low Golgi $\mathrm{O}_{2}{ }^{\cdot-}$ levels decreased the caspase-2 level. Furthermore, excess $\mathrm{O}_{2}{ }^{-{ }^{-}}$induced apoptosis, as evidenced by the results of the flow cytometry experiment presented in Fig. 5B. Correspondingly, decreased $\mathrm{O}_{2}{ }^{--}$levels with Tiron $(10 \mu \mathrm{M})$ could inhibit apoptosis. Based on these data, excess $\mathrm{O}_{2}{ }^{--}$levels in the Golgi apparatus provide a signal to increase caspase 2 levels and apoptosis.

\section{TNF- $\alpha$ induced $\mathrm{O}_{2}{ }^{\cdot-}$ generation in the Golgi apparatus}

TNF- $\alpha$ plays an important role in hepatic IR injury. ${ }^{42}$ Therefore, we explored the relationship between TNF- $\alpha$ and Golgi $\mathrm{O}_{2}{ }^{--}$ levels. In Fig. S6 and S7, $\dagger$ we observed higher levels of TNF- $\alpha$ in IR cells compared with normal cells (TNF- $\alpha$ kit) and high Golgi $\mathrm{O}_{2}{ }^{\cdot-}$ concentrations. After the addition of a TNF- $\alpha$ inhibitor $\left(100 \mu \mathrm{g} \mathrm{mL}{ }^{-1}\right.$ silymarin $),{ }^{43}$ the blue fluorescence of IR cells changed slightly, indicating that TNF- $\alpha$ inhibition decreased Golgi $\mathrm{O}_{2}{ }^{--}$levels in IR cells comparing with cells in which TNF$\alpha$ was not inhibited. Thus, TNF- $\alpha$ was located upstream of $\mathrm{O}_{2}{ }^{--}$ generation in the Golgi apparatus and the signal for IR injury is TNF- $\alpha-\mathrm{O}_{2}{ }^{-}$-caspase 2-apoptosis (Fig. 6).

\section{Conclusions}

We developed a two-photon fluorescence probe for the dynamic and reversible detection of $\mathrm{O}_{2}{ }^{\cdot-}$ levels in the Golgi apparatus and to determine the relationship between $\mathrm{Golgi}_{2}{ }^{\cdot--}$ levels and IR injury. Using two-photon fluorescence microscopy, we imaged excess $\mathrm{O}_{2}{ }^{-{ }^{-}}$levels in the Golgi apparatus and studied the connections between TNF- $\alpha, \mathrm{O}_{2}{ }^{-}$and caspase-2. Furthermore, we provided a potential mechanism of the signal transduction pathway mediated by Golgi $\mathrm{O}_{2}{ }^{\cdot-}$ during the IR process, which provides new insights into potential treatments for hepatic IR injury.

\section{Conflicts of interest}

There are no conflicts to declare.

\section{Acknowledgements}

This work was supported by the National Natural Science Foundation of China (21535004, 91753111, 21705100, 21675105, 21475079 and 21390411), National Major Scientific and Technological Special Project for "Significant New Drugs Development" (2017ZX09301030004), Key Research and Development Program of Shandong Province (2018YFJH0502), Natural Science Foundation of Shandong Province (ZR2017BB066 and ZR2017ZC0225) and a project of Shandong Province Higher Educational Science and Technology Program (J16LC09).

\section{Notes and references}

1 F. Serracinoinglott, N. A. Habib and R. T. Mathie, Am. J. Surg., 2001, 181, 160-166.

2 R. A. Gottlieb, K. O. Burleson, R. A. Kloner, B. M. Babior and R. L. Engler, J. Clin. Invest., 1994, 94, 1621-1628.

3 T. H. Sanderson, C. A. Reynolds, R. Kumar, K. Przyklenk and M. Huettemann, Mol. Neurobiol., 2013, 47, 9-23.

4 A. Koo, H. Komatsu, G. Tao, M. Inoue, P. H. Guth and N. Kaplowitz, Hepatology, 2010, 15, 507-514.

5 W. Zhang, P. Li, F. Yang, X. Hu, C. Sun, W. Zhang, D. Chen and B. Tang, J. Am. Chem. Soc., 2013, 135, 14956-14959.

6 B. González-Flecha, J. C. Cutrin and A. Boveris, J. Clin. Invest., 1993, 91, 456-464.

7 C. Szabo, Shock, 1996, 6, 79-88.

8 B. C. Dickinson and C. J. Chang, Nat. Chem. Biol., 2011, 7, 504-511.

9 S. Munro, Trends Cell Biol., 1998, 8, 11-15.

10 T. J. Guzik, R. Korbut and T. Adamekguzik, J. Physiol. Pharmacol., 2003, 54, 469-487.

11 E. T. Chouchani, V. R. Pell, A. M. James, L. M. Work, K. SaebParsy, C. Frezza, T. Krieg and M. P. Murphy, Cell Metab., 2016, 23, 254-263.

12 P. Zhang, X. X. Yang, Y. Wang, N. W. Zhao and C. Z. Huang, Nanoscale, 2014, 6, 2261-2269.

13 J. V. Frangioni, Curr. Opin. Chem. Biol., 2003, 7, 626-634.

14 X. Chen, X. Tian, I. Shin and J. Yoon, Chem. Soc. Rev., 2011, 40, 4783-4804.

15 J. Du, M. Hu, J. Fan and X. Peng, Chem. Soc. Rev., 2012, 41, 4511. 
16 H.-W. Liu, K. Li, X.-X. Hu, L. Zhu, Q. Rong, Y. Liu, X.-B. Zhang, J. Hasserodt, F.-L. Qu and W. Tan, Angew. Chem., 2017, 129, 11950-11954.

17 H. K. Kim, J. Liu, J. Li, N. Nagraj, M. Li, C. M. Pavot and Y. Lu, J. Am. Chem. Soc., 2007, 129, 6896-6902.

18 F. Helmchen and W. Denk, Nat. Methods, 2005, 2, 932-940.

19 W. Zhang, X. Wang, P. Li, H. Xiao, W. Zhang, H. Wang and B. Tang, Anal. Chem., 2017, 89, 6840-6845.

20 L. Zhou, X. Zhang, Q. Wang, Y. Lv, G. Mao, A. Luo, Y. Wu, Y. Wu, J. Zhang and W. Tan, J. Am. Chem. Soc., 2014, 136, 9838-9841.

21 X. Chen, F. Wang, J. Y. Hyun, T. Wei, J. Qiang, X. Ren, I. Shin and J. Yoon, Chem. Soc. Rev., 2016, 45, 2976-3016.

22 H.-W. Liu, L. Chen, C. Xu, Z. Li, H. Zhang, X.-B. Zhang and W. Tan, Chem. Soc. Rev., 2018, 47, 7140-7180.

23 G. Mao, T. Wei, X. Wang, S. Huan, D. Lu, J. Zhang, X. Zhang, W. Tan, G. Shen and R. Yu, Anal. Chem., 2013, 85, 7875-7881.

24 W. Zhang, X. Wang, P. Li, H. Xiao, W. Zhang, H. Wang and B. Tang, Anal. Chem., 2017, 89, 6840-6845.

25 W. Zhang, P. Li, F. Yang, X. F. Hu, C. Z. Sun, W. Zhang, D. Z. Chen and B. Tang, J. Am. Chem. Soc., 2013, 135, 14956-14959.

26 P. Li, W. Zhang, K. Li, X. Liu, H. Xiao, W. Zhang and B. Tang, Anal. Chem., 2013, 85, 9877-9881.

27 P. Li, L. Liu, H. Xiao, W. Zhang, L. Wang and B. Tang, J. Am. Chem. Soc., 2016, 138, 2893-2896.

28 X. Gao, C. Ding, A. Zhu and Y. Tian, Anal. Chem., 2014, 86, 7071-7078.

29 J. J. Hu, N.-K. Wong, S. Ye, X. Chen, M.-Y. Lu, A. Q. Zhao, Y. Guo, A. C.-H. Ma, A. Y.-H. Leung, J. Shen and D. Yang, J. Am. Chem. Soc., 2015, 137, 6837-6843.
30 R. S. Li, P. F. Gao, H. Z. Zhang, L. L. Zheng, C. M. Li, J. Wang, Y. F. Li, F. Liu, N. Li and C. Z. Huang, Chem. Sci., 2017, 8, 6829-6835.

31 D. Aoki, N. Lee, N. Yamaguchi, C. Dubois and M. N. Fukuda, Proc. Natl. Acad. Sci. U. S. A., 1992, 89, 4319-4323.

32 Y. Maeda, G. V. Beznoussenko, J. Van Lint, A. A. Mironov and V. Malhotra, EMBO J., 2001, 20, 5982-5990.

33 H. Maeda, K. Yamamoto, Y. Nomura, I. Kohno, L. Hafsi, N. Ueda, S. Yoshida, M. Fukuda, Y. Fukuyasu and Y. Yamauchi, J. Am. Chem. Soc., 2005, 127, 68-69.

34 D. Oushiki, H. Kojima, T. Terai, M. Arita, K. Hanaoka, Y. Urano and T. Nagano, J. Am. Chem. Soc., 2010, 132, 2795-2801.

35 P. Huang, L. Feng, E. A. Oldham, M. J. Keating and W. Plunkett, Nature, 2000, 407, 390.

36 Y. Zhou, E. O. Hileman, W. Plunkett, M. J. Keating and P. Huang, Blood, 2003, 101, 4098-4104.

37 Y. Du, C. M. Miller and T. S. Kern, Free Radical Biol. Med., 2003, 35, 1491-1499.

38 M. Y. Chang, A. L. Shiau, Y. H. Chen, C. J. Chang, H. W. Chen and C. L. Wu, Cancer Sci., 2008, 99, 1479-1484.

39 J. Adler and I. Parmryd, Cytometry, Part A, 2010, 77, 733-742.

40 R. Liu, L. Zhang, X. Lan, L. Li, T. T. Zhang, J. H. Sun and G. H. Du, Neuroscience, 2011, 176, 408-419.

41 S. Thiberge, S. Blazquez, P. Baldacci, O. Renaud, S. Shorte, R. Ménard and R. Amino, Nat. Protoc., 2007, 2, 1811-1818.

42 M. Serteser, T. Koken, A. Kahraman, K. Yilmaz, G. Akbulut and O. N. Dilek, J. Surg. Res., 2002, 107, 234-240.

43 X. Zi, H. Mukhtar and R. Agarwal, Biochem. Biophys. Res. Commun., 1997, 239, 334-339. 